\title{
Imunoexpressão das proteinas ciclooxigenase-2 e p53 em carcinomas de mama ductais in situ e invasivo concomitantes
}

Cyclooxygenase-2 and p53 immunohistochemical expression in simultaneous ductal carcinoma in situ and invasive ductal carcinoma

Autora: Maria Marta Martins Orientador: Prof. Dr. Sebastião Piato

Tese apresentada à Faculdade de Ciências Médicas da Santa Casa de São Paulo para a obtenção do Título de Doutor em Medicina, em 18 de agosto de 2006.

Objetivos: acredita-se que no câncer de mama, ocorra uma expressão mais ativa da ciclooxigenase-2 (COX-2) quando comparada aos tecidos normais, por mecanismos ainda não bem elucidados. Associado a este mecanismo parece ocorrer também a inativação de genes supressores, como o TP53. Dentro deste contexto, este trabalho teve por objetivo avaliar a correlação entre a expressão das proteínas COX-2 e p53 em carcinomas de mama ductais in situ (CDIS) e invasivo (CDI) simultâneos. Métodos: cortes histológicos de 47 espécimes cirúrgicos, estudados pela técnica de imunoistoquímica, com o uso de anticorpos anti-p53 e anti-COX-2. Os cortes foram classificados em escores de zero a três, de acordo com a intensidade e o número de células coradas; foram considerados negativos os escores zero e um e positivos os dois e três. Resultados: expressão da COX-2 foi notada no CDIS, CDI e no epitélio normal em $41(87 \%), 40(85 \%)$ e $35(74,5 \%)$ casos, respectivamente. A p53 foi positiva em 20 (42,6\%) casos de CDI e em 21 $(44,7 \%)$ casos dos CDIS. Não houve marcação para a p53 nos epitélios normais. Conclusões: não obtivemos correlação entre a expressão da COX-2 e a da p53 nos compartimentos histológicos estudados. Avaliando a correlação entre as expressões das proteínas frente o grau nuclear, a presença de comedonecrose, o grau histológico, o tamanho tumoral e a faixa etária, não observamos correlação.

PALAVRAS-CHAVE: Prostaglandina-endoperóxido-sintase; Imunoistoquímica; Carcinoma ductal de mama; Carcinoma in situ; Proteína p53

\section{Correlação entre os resultados da Citologia, Captura Híbrida, nested PCR PGMY/GP+ e PCR tipo-especíico na infecção por Papilomavirus humano}

Citology, Hybrid Capture, nested PCR PGMY/GP+ and Type-specific PCR correlation in Human papillomavirus infection

Autora: Inês Aparecida Tozetti

Orientador: Prof. Dr. Antonio Walter Ferreira

Tese apresentada ao Programa de Pós-Graduação do Instituto de Ciências Biomédicas da Universidade de São Paulo, para obtenção do título de Doutor em Ciências na área de Concentração Imunologia, em 14 de fevereiro de 2006.

O Papilomavirus humano (HPV) está associado com um amplo espectro de lesões em humanos, incluindo verrugas e displasias do epitélio genital. A infecção persistente do trato genital feminino, por alguns tipos de HPV, pode levar às neoplasias intraepiteliais cervicais (NIC) e carcinomas invasivos. Atualmente, conhece-se mais de 230 tipos de HPV, sendo que alguns são considerados como de alto risco oncogênico (tipos 16, 18, 31, 33, 35, $39,45,51,52,56,58,59,66$ e 68), enquanto outros, como de baixo risco oncogênico (tipos $6,11,42,43$ e 44). A forte associação entre o HPV e o câncer de colo de útero torna importante estudarmos a eficiência dos métodos atualmente utilizados para detecção de HPV ou simples triagem do paciente. No presente estudo, 465 pacientes atendidas no Centro de Prevenção ao Câncer, em Campo Grande - MS, e submetidas à Citologia foram analisadas por Captura Híbrida 2 (HCII), nested PCR PGMY/GP+(nPCR) e PCR tipo-específico. A correlação entre esses métodos mostrou concordância de $61 \%$ entre as técnicas de citologia e HCII e de 80,5\% (kappa = 0,79) entre as técnicas de nPCR e HCII. A positividade para os tipos de alto risco oncogênico foi maior entre as amostras com alterações citológicas. Observamos correlação positiva entre a mediana da carga viral, para o grupo de alto risco oncogênico e lesões intraepiteliais de baixo e alto grau. A freqüência de infecção por múltiplos tipos foi de 20,7\%, e os tipos mais freqüentes foram HPV6/11, HPV66 e o HPV45. Não houve relação entre alterações citológicas e infecção por múltiplos tipos ou algum tipo viral em particular.

PALAVRAS CHAVES: Papilomavírus humano; Diagnóstico; PCR; Captura Híbrida e Citologia oncótica 